\title{
FEMALE STUDENTS VIEW THE KNOWLEDGE OF FOREIGN LAN- GUAGES AS MORE IMPORTANT FOR CAREERS IN TOURISM THAN MALE STUDENTS?
}

\author{
Nikolina Božinović1, Joško Sindik ${ }^{2}$ \\ Rochester Institute of Technology, RIT Croatia, Dubrovnik, Croatia ${ }^{1}$; Institute for anthropological research, Zagreb, Croatia ${ }^{2}$
}

\begin{abstract}
The proficiency in multiple foreign languages is a basic assumption for successful communication in tourism. Tourism and mobility have a significant and important role, where intercultural contacts contribute to the development of intercultural dialogue. This paper attempts to explore gender differences in the perceptions of students from the Rochester Institute of Technology, RIT Croatia regarding the importance of knowing various foreign languages in tourism. The results obtained could help in raising the awareness of the importance of the role of learning and teaching foreign languages, with potential effects in developing and promoting tourism in Croatia. The key research finding is that the female students generally consider knowing foreign languages as more important than male students. This finding could indicate that women are potentially more demanding tourists. However, in most variables the study failed to find any statistically significant differences.
\end{abstract}

Keywords

communicative competence, intercultural communication in tourism, responsible tourism, gender differences

\section{Language proficiency in Europe today}

In today's globalized world, the importance of knowing foreign languages is a necessity and multilingualism is viewed as an investment in the future. In Europe, languages have long been a fundamental and integral part of educational programs. With the continued expansion of the European Union, European language policies are moving towards the teaching of 'at least two foreign languages from a very early age' and describe the knowledge of foreign languages as a 'basic skill' /1/.

The proficiency in multiple foreign languages is a basic assumption for successful communication in tourism. It is indisputable to state that in today's world of globalization, tourism and mobility also have a significant and important role, where intercultural contacts contribute to the development of intercultural dialogue. Foreign language proficiency plays the key role in the development of tourism which on itself has a multiple role and is viewed as economic, social and cultural activity. Therefore, it is indisputable to state that this knowledge represents one of the most important activities of the modern, contemporary society around the world, and especially in Europe /2/.

All European educational systems attach ever-increasing importance to the learning of foreign languages. There is a strong need to educate multilingual and multicultural individuals in a context where the linguistic consequences of globalization are more and more evident. The globalization process is forcing European educational systems to pay more attention to the learning of foreign languages. Therefore European schools and institutions of higher education are continually offering courses taught in foreign languages thus exposing students to teaching through the medium of foreign language. Lasagabaster /3/ points out that one of the most important issues in many European education systems is whether it is better to start foreign language teaching at an early age, or whether it is 
better to include Content and Language Integrated Learning (CLIL) at a later stage without establishing an early first contact with the foreign language. The research undertaken in naturalistic settings confirms that students who start learning a foreign language at an early age ultimately achieve higher competence in the L2. Numerous empirical studies in the field of Second Language Acquisition (SLA) have shown that children who start learning a second language before adolescence exhibit more native-like pronunciation and are more likely to become fluent speakers. The critical period hypothesis states that there is a period when language acquisition takes place naturally and effortlessly /4/ . It is argued that the optimum age for language acquisition falls within the first ten years of life. During this period the brain retains plasticity, but with the onset of puberty this plasticity begins to disappear. Recent findings in brain research indicate that the specialized functions of specific regions of the brain are not fixed at birth but are shaped by experience and learning. This means that we should promote the importance of learning more than one foreign language in the early age. It must, however, be emphasized that L2 learners vary considerably both in how quickly they learn and how successful they are. The evidence so far suggests that the explanation for this could be found in differences in personal and general factors /4/. Dörnyei /5/ pointed out that second language learners vary on a number of dimensions that have to do with personality, motivation, learning style, learning strategies, aptitude and age.

\section{Intercultural communication in tourism}

According to the Common European Framework of Reference for Languages /6/ communicative language competence is seen as a key competence in modern foreign language teaching. One of the most popular approaches of communicative competence defines this competence as knowledge and skills necessary for communication $/ 7 /$. Bachman and Palmer $/ 8 /$, on the other hand, consider that communicative competence is connected with morphology, syntax, lexis, cohesion and organization of the text. Tarone and Yule /9/ further elaborated Canale and Swain's classifications of communicative competence and they associate communicative competence with an ability to form and understand syntax, lexis, phonology of the language and an ability to use a language according to the socio-cultural context in which it is spoken. It is also seen as an ability to effectively pass information to the partner, including an ability to use different communication strategies in order to solve problems that have arisen in the communication process.

In the field of tourism, beside the communicative language competence it is extremely important to develop the intercultural competence, or the ability of successful communication between members of different cultures. The process of globalization has indeed opened many doors thus forcing us to recognize the existing differences and diversities of people living in European Union. Still, it is an ongoing process to learn how to recognize, respect and learn to appreciate those differences. According to the Common European Framework of Reference for Languages /6/ knowledge, awareness and understanding of the relation between the "world of origin' and the 'world of the target community' produce this intercultural awareness. It is, of course, important to note that intercultural awareness includes an awareness of regional and social diversity in both worlds. This process is also enriched by the awareness of a wider range of cultures than those carried by the learner's L1 and L2. This wider awareness helps to place both languages in context. In addition to objective knowledge, intercultural awareness covers an awareness of how each community appears from the perspective of the other, often in the form of national stereotypes. Intercultural skills and different know-how skills include the ability to bring the culture of origin and the foreign culture into relation with each other. Those skills also help develop the cultural sensitivity and the ability to identify and use a variety of strategies to contact interlocutors from other cultures. Those strategies should also include the capacity to fulfill the role of cultural intermediary between one's own culture and the foreign culture and to deal effectively with intercultural misunderstanding and conflict situations as well as the ability to overcome stereotyped relationships /6/. Dörnyei and Scizér /10/ pointed out that intercultural contact is also a key issue in second language (L2) acquisition for at least two reasons. On one hand, one of the main aims of learning second languages has traditionally been seen to establish meaningful contact across cultures, because L2 proficiency creates the medium of communication between members of 
different ethno linguistic communities. On the other hand, interethnic contact also creates opportunities for developing language skills and acts as a powerful influence shaping the learners' attitudinal/motivational disposition, thereby promoting motivated learning behavior. Thus, intercultural contact is both a means and an end in L2 studies $/ 10 /$.

As already stated before, languages and intercultural competence represent an economic imperative in the European context $/ \mathbf{1} /$. It is clear that the phenomenon of globalization has led to the dramatic rise of usage of English as 'the global language'. It is also well known that many millions of people in countries all over the world are learning this language, so the knowledge of English more and more comes to be seen as a 'universal basic skill' or, the language itself as lingua fran$c a$. But even though the number of people using English as a lingua franca is increasing steadily, this does not necessarily mean that this language will be the only language used in the future. This thesis is also supported by Graddol /in 11/ who points out that 'English will indeed play a crucial role in shaping the new world linguistic order, but its major impact will be in creating new generations of bilingual and multilingual speakers across the world'.

\section{Intercultural competence for professionals in tourism and hospitality}

It is evident that in the field of tourism and hospitality it is extremely important to develop not only communicative language competence but also the intercultural competence, or the ability of successful communication between members of different cultures. In the process of learning a new language it is important to be aware of its cultural aspect(s), because the knowledge of other cultures helps a learner to learn and to understand a certain language and to assess cultural values of that language $/ \mathbf{1 2} /, / \mathbf{1 3} /$. According to Byram $/ \mathbf{1 4} /$, intercultural competence includes attitude, knowledge, interpretation and related skills, various discovery and interaction skills, as well as critical awareness of culture or political education. In order to develop intercultural competence, students should not only learn a foreign language, but such a process should also include intercultural training and intercultural exchange of ideas. It is evident that the knowledge and the skills acquired in this learning process will highly contribute to the development of tourism and hospitality services in general.

Students of tourism, hospitality and management also have to acquire theoretical and practical cultural knowledge, which can be gained through intercultural communication and the development of intercultural competence /15/. Intercultural competence is mostly referred to as an ability to see and understand differences in one's own and other people's culture, to accept them and accordingly react. At the same time this competence includes the knowledge of one's own nation and culture, and the awareness of its values as well as the necessity of their preservation /16/. If we transfer this into the area of tourism and hospitality, and try to distinguish what is important to know about the language that hotel and restaurant employees use, we will soon realize that it is not only the knowledge of the grammar and vocabulary that needs to be applied but the awareness of the importance of socio-cultural aspect as well /17/. Although their grammatical and their lexical competence of a foreign language may be outstanding it still can cause cultural misunderstanding, or a final failure in communication with native speakers. Petrovska /17/ points out that this failure may be a result of lack of knowledge of cultural differences between the two (or more) societies, or the influence of their mother tongue and direct transfer of meaning in the other language. They simply may not know how to handle cultural differences or how to see what they are at the first place. This, for example, is of utmost importance for the communicative competence of human resources employees.

Language has become the true manifestation of a culture and people's value systems. According to Petrovska $/ \mathbf{1 7} /$, the language is the most important medium of human communication, since it serves as a vessel to express information, ideas, emotions, attitudes and so many other things. Due to multiple functions and roles of language in humans and in our societies as a whole it is crucial that we all recognize that the world we all live in is influenced by a series of interlocking cultures, and it is not a unique, uniformed cultural model. Those different cultures influence the way we perceive and view our world, and the multiplicity of such a world influences the ways we make our decisions and how we interact with others. National cultures, on the other hand, also have an enormous influence on 
people's values, attitudes and behaviors. Therefore, in order to function better in the real world, people from different cultures have to negotiate, and learn how to understand and respect better the behavior and reactions of people from other cultures. The authors of this article feel that this awareness is an extremely important factor for consideration, especially in tourism since multicultural groupings are becoming more common in this area. Therefore, this approach should be a part of learning strategies in teaching foreign languages to students of hospitality and tourism.

In view of the aforementioned importance of foreign languages for careers in tourism, the objective of our research was to identify gender differences in the importance of the knowledge of selected foreign languages for the improvement of overall hospitality services offer in Dubrovnik. Additionally, we also wanted to investigate gender differences in the perceptions of students from the Rochester Institute of Technology, RIT Croatia regarding the importance of knowing various foreign languages in different tourist categories in the overall tourist offer, such as cultural tourism, congress tourism, nautical tourism and ecotourism, as well as to identify which foreign languages they consider to be important for specific types of tourism. Gender differences were also considered in the identification of the importance of foreign language skills in different institutions and organizations, such as hotels, restaurants, institutions of local government, tourist board and public sector that are responsible for the development of the city of Dubrovnik as a tourist destination. Finally, our research aimed to find gender differences in the student's perception of the difficulty of learning certain foreign languages. Our initial hypothesis was that we would find no gender differences in any of previously defined areas, as all participants have almost the same education level and most of them live in the same town. So, we can't have proper arguments for gender bias in the evaluation of the factors connected with the importance of foreign languages for careers in tourism.

\section{Methodology}

\section{Instrument}

The importance of the knowledge of foreign languages was examined by a questionnaire that was designed by one of the authors of this paper in previous research /15/. This questionnaire is a semi-structured questionnaire, divided into 6 categories of questions which examine the importance of the knowledge of foreign languages in specific areas of tourism. A five-point scale was used to evaluate the degree of importance of foreign languages in each tourism category (1'not important', 2- 'slightly important', 3- 'moderately important', 4- 'very important', 5- 'most important'). In the first category of the questionnaire the participants had to rate the importance of knowledge of a particular foreign language in improving the overall hospitality services offer in Dubrovnik. In the second category the participants had to rate the importance of the knowledge of different foreign languages for different types of tourism (cultural, congress, nautical and ecotourism). In the third category the participants had to rate the importance of the knowledge of foreign languages for elite and mass tourism. In the fourth category the participants had to rate the importance of knowledge of foreign languages in different institutions and organizations that are responsible for the development of the city of Dubrovnik as a tourist destination, i.e. in hotels, restaurants, coffee bars, institutions of local government and self-government, tourist board and public sector (medical institutions, public transportation, banks etc.) In the last category, participants were given a task to rank the languages concerning the difficulty of learning certain foreign languages (1- 'most difficult to learn', 2- 'difficult', 3- 'neither difficult nor easy', 4'easy', 5 - 'easiest'). The questionnaire also provided some demographic data on the participants (gender, age, language learning level, mother tongue, first (L1) and second (L2) foreign language.

\section{Participants}

A total of 107 participants that are currently attending RIT Croatia participated in this survey. There were 58 male (54.2\%) and 49 female $(45.8 \%)$ participants. 46 of them $(43 \%)$ were senior students, while 61 of them $(57 \%)$ were the students in their third year of study (junior students). It is important to mention that all participants were enrolled in Hospitality and Service Management Program (HSM). 89 participants (83.2\%) were native speakers of Croatian, while 18 participants $(16.8 \%)$ were native speakers of one of the following languages: Bosnian, English, Macedonian, 
Montenegrin, Albanian, German, Norwegian and Italian. For 91 participants (85\%) English was their first foreign language. 28 participants $(26.2 \%)$ took German as their second foreign language while 40 participants took Italian (37.4\%) as their second foreign language. 11 participants $(10.3 \%)$ took French as their second foreign language, 22 participants $(20.6 \%)$ took Spanish as their second foreign language, 5 participants learned English $(4.7 \%)$ as their second foreign language, and for 1 participant $(0.9 \%)$ Russian was his second foreign language. Most of our participants had already previously studied relative foreign languages: 38 participants $(35.5 \%)$ stated that they had been studying their second foreign language for more than 6 years, 33 participants $(30.8 \%)$ stated they had been studying their second foreign language for more than two years, while 16 of them (15\%) stated that they had been studying their second foreign language for already more than 4 years. As to an answer to the question how many languages they speak, 52 participants $(48.6 \%)$ declared to speak two foreign languages, 29 participants $(27.1 \%)$ three foreign languages, while 12 of them $(11.2 \%)$ declared to speak four foreign languages.

\section{Data collection and analysis}

All the data in this questionnaire were collected during regular classes at RIT Croatia and its participants were not informed beforehand about the survey. The survey was anonymous, in order to provide sincere and honest answers to questions. Data analysis was performed using ttest for independent samples and Chi-square test and the data from the questionnaire were analyzed using statistical package SPSS 11.0.

\section{Results and discussion}

Gender differences in the perception of students from RIT Croatia regarding the importance of knowing various foreign languages for the improvement of the overall hospitality services offer were analyzed. As shown in Table 1, three statistically significant gender differences among students with regard to the role of the most important foreign languages in the hospitality industry in Dubrovnik were found. Female students estimate Italian, German and French as more important foreign languages for the improvement of the overall hospitality services offer, comparing with male students. A simple explanation can lead us to presume that female students estimate the communicative aspect (using certain foreign languages in communication) as more important than male students (or men at all).

Table 1 T-tests concerning the importance of the knowledge of foreign languages for the improvement of the overall hospitality services offer according to the participants' gender

\begin{tabular}{|l|c|c|c|c|c|c|}
\hline \multicolumn{1}{|c|}{ VARIABLE } & $\begin{array}{c}\mathrm{t} \text {-test } \\
(\mathrm{df}=105)\end{array}$ & $\mathrm{P}$ & $\begin{array}{c}\mathrm{M} \\
\text { male }\end{array}$ & $\begin{array}{c}\sigma \\
\text { male }\end{array}$ & $\begin{array}{c}\mathrm{M} \\
\text { female }\end{array}$ & $\begin{array}{c}\sigma \\
\text { female }\end{array}$ \\
\hline English & -.272 & $>.20$ & 4.83 & .625 & 4.86 & .500 \\
\hline German & $\mathbf{- 1 . 9 9 1}$ & $<.05$ & 3.55 & 1.095 & 3.90 & .684 \\
\hline Italian & $\mathbf{- 2 . 7 4 5}$ & $<.01$ & 3.52 & 1.096 & 4.00 & .707 \\
\hline French & $\mathbf{- 2 . 7 7 8}$ & $<.01$ & 3.05 & 1.176 & 3.61 & .909 \\
\hline Spanish & -1.163 & $>.20$ & 3.38 & .952 & 3.59 & .934 \\
\hline Russian & -1.194 & $>.20$ & 3.09 & 1.247 & 3.35 & 1.011 \\
\hline
\end{tabular}

Legend: $\mathrm{M}=$ Mean; $\sigma=$ Standard Deviation

As indicated in Table 2, there are no statistically significant gender differences with regard to the importance of a foreign language in various types of tourism. However, for all types of tourism, we can observe non-significant trend of higher means among female students. 
Table 2 T-tests concerning the importance of the types of tourism according to participants' gender

\begin{tabular}{|l|c|c|c|c|c|c|}
\hline \multicolumn{1}{|c|}{ VARIABLE } & $\begin{array}{c}\mathrm{t} \text {-test } \\
(\mathrm{df}=105)\end{array}$ & $\mathrm{p}$ & $\begin{array}{c}\mathrm{M} \\
\mathrm{male}\end{array}$ & $\begin{array}{c}\sigma \\
\text { male }\end{array}$ & $\begin{array}{c}\mathrm{M} \\
\text { female }\end{array}$ & $\begin{array}{c}\sigma \\
\text { female }\end{array}$ \\
\hline Cultural tourism & -.018 & $>.20$ & 4.57 & .775 & 4.57 & .645 \\
\hline Congress tourism & -1.636 & $>.10$ & 3.79 & .894 & 4.06 & .801 \\
\hline Nautical tourism & -.375 & $>.20$ & 3.72 & 1.022 & 3.80 & .957 \\
\hline Ecotourism & -.497 & $>.20$ & 3.55 & .976 & 3.65 & 1.110 \\
\hline
\end{tabular}

Legend: $\mathrm{M}=$ Mean; $\sigma=$ Standard Deviation

As shown in Table 3, no gender differences were found with regard to the importance of the knowledge of different foreign languages for different types of tourism. Both genders stated that English is the most important language for the development of all types of tourism. This fact confirms our initial hypothesis that English has become a global language. It is already a wellknown fact that many millions of people in countries all over the world learn English which more and more comes to be seen as a 'universal basic skill' or 'lingua franca'.

Table 3 Chi square-tests about the importance of the knowledge of different foreign languages for different types of tourism according to participants' gender

\begin{tabular}{|c|c|c|c|c|c|c|c|}
\hline & English & German & Italian & French & Spanish & Russian & $\begin{array}{l}\text { Chi } \\
\text { square }\end{array}$ \\
\hline & \multicolumn{7}{|c|}{ Important for development of cultural tourism } \\
\hline Male & 53 & 1 & 1 & 2 & 1 & & \multirow[t]{2}{*}{.864} \\
\hline Female & 46 & 1 & & 2 & & & \\
\hline & \multicolumn{7}{|c|}{ Important for development of nautical tourism } \\
\hline Male & 51 & & 7 & & 1 & 2 & \multirow[t]{2}{*}{.299} \\
\hline Female & 40 & & 6 & & 1 & 2 & \\
\hline & \multicolumn{7}{|c|}{ Important for development of ecotourism } \\
\hline Male & 53 & 4 & & 1 & & & \multirow[t]{2}{*}{.465} \\
\hline Female & 45 & 2 & 1 & & 1 & & \\
\hline & \multicolumn{7}{|c|}{ Important for development of congress tourism } \\
\hline Male & 56 & 1 & 1 & & & & \multirow[t]{2}{*}{.649} \\
\hline Female & 48 & & 1 & & & & \\
\hline
\end{tabular}

Note: all Chi-square tests are non-significant

As indicated in Table 4, there are no statistically significant gender differences with regard to the importance of the knowledge of foreign languages for elite and mass tourism. However, we can note again a non-significant trend of higher means among female students.

Table 4 T-test concerning the importance of the knowledge of foreign languages for elite and mass tourism according to participants' gender

\begin{tabular}{|l|c|c|c|c|c|c|}
\hline \multicolumn{1}{|c|}{ VARIABLE } & $\begin{array}{c}\mathrm{t} \text {-test } \\
(\mathrm{df}=105)\end{array}$ & $\mathrm{p}$ & $\begin{array}{c}\mathrm{M} \\
\text { male }\end{array}$ & $\begin{array}{c}\sigma \\
\text { male }\end{array}$ & $\begin{array}{c}\mathrm{M} \\
\text { female }\end{array}$ & $\begin{array}{c}\sigma \\
\text { female }\end{array}$ \\
\hline Mass tourism & -1.366 & $>.10$ & 3.81 & 1.290 & 4.12 & 1.073 \\
\hline Elite tourism & -.471 & $>.20$ & 4.74 & .579 & 4.80 & .612 \\
\hline
\end{tabular}

Legend: $M=$ Mean; $\sigma=$ Standard Deviation

The results in Table 5 show that there are no statistically significant gender differences with regard to the importance of the knowledge of foreign languages in different institutions and organizations, such as hotels, restaurants, coffee bars, institutions of local government, tourist board and public sector that are responsible for the development of the city of Dubrovnik as a tourist destination. We can note again the non-significant trend of higher means among female students, compared with male ones. 
Table 5 T-test concerning the importance of the knowledge of foreign languages for different institutions and organizations according to participants' gender

\begin{tabular}{|l|c|c|c|c|c|c|}
\hline \multicolumn{1}{|c|}{ VARIABLE } & $\begin{array}{c}\mathrm{t} \text {-test } \\
(\mathrm{df}=105)\end{array}$ & $\mathrm{p}$ & $\begin{array}{c}\mathrm{M} \\
\mathrm{male}\end{array}$ & $\begin{array}{c}\sigma \\
\text { male }\end{array}$ & $\begin{array}{c}\mathrm{M} \\
\text { female } \\
\text { female }\end{array}$ \\
\hline hotels, restaurants, coffee bars & -.835 & $>.20$ & 4.64 & .667 & 4.73 & .531 \\
\hline $\begin{array}{l}\text { institutions of local government and } \\
\text { self-government }\end{array}$ & -.112 & $>.20$ & 4.00 & .955 & 4.02 & .924 \\
\hline tourist board & -1.502 & $>.10$ & 4.53 & .706 & 4.73 & .670 \\
\hline public sector & -1.495 & $>.10$ & 4.07 & .792 & 4.29 & .707 \\
\hline
\end{tabular}

Legend: $M=$ Mean; $\sigma=$ Standard Deviation

As indicated in Table 6, the study has revealed a few statistically significant gender differences with regard to the importance of the knowledge of certain foreign languages for different services, such as waiters, receptionists, taxi drivers, and tourist agency employees. It can be noted there is a strong trend of statistically significant higher means among female students in comparison to the male students. Among the statistically significant gender differences (according to type of ser- vice), we can note that most of the differences are found for the waiters (four) and tourist agency employees and receptionists (three). There are no statistically significant gender differences (according to type of service) found for: cooks, chambermaids, hotel managers and public sector employees. Among statistically significant gender differences, the most differences were found in Italian and French (three).

Table 6 T-tests concerning the importance of the knowledge of certain foreign languages for different services according to the participants' gender (only statistically significant tests were indicated)

\begin{tabular}{|l|c|c|c|c|c|c|}
\hline \multicolumn{1}{|c|}{ service - language } & $\begin{array}{c}\mathrm{t} \text {-test } \\
(\mathrm{df}=105)\end{array}$ & $\mathrm{p}$ & $\begin{array}{c}\mathrm{M} \\
\text { male }\end{array}$ & $\begin{array}{c}\sigma \\
\text { male }\end{array}$ & $\begin{array}{c}\mathrm{M} \\
\text { female }\end{array}$ & $\begin{array}{c}\sigma \\
\text { female }\end{array}$ \\
\hline waiter - German & $\mathbf{- 2 . 5 8 3}$ & $<.01$ & 3.41 & 1.044 & 3.90 & .895 \\
\hline waiter - Italian & $\mathbf{- 2 . 7 0 2}$ & $<.01$ & 3.41 & .956 & 3.90 & .895 \\
\hline waiter - Spanish & $\mathbf{- 2 . 1 9 9}$ & $<.05$ & 3.33 & 1.015 & 3.76 & .990 \\
\hline waiter - French & $\mathbf{- 2 . 7 7 8}$ & $<.01$ & 3.00 & 1.243 & 3.63 & 1.112 \\
\hline receptionist - German & $\mathbf{- 2 . 0 1 3}$ & $<.05$ & 4.07 & .934 & 4.39 & .702 \\
\hline receptionist - Italian & $\mathbf{- 2 . 2 8 4}$ & $<.05$ & 4.09 & .844 & 3.90 & .872 \\
\hline receptionist - French & $\mathbf{- 2 . 7 6 6}$ & $<.01$ & 3.71 & 1.108 & 4.22 & .823 \\
\hline taxi driver - English & $\mathbf{- 2 . 4 4 3}$ & $<.05$ & 3.86 & .868 & 4.27 & .836 \\
\hline tourist agency employee - Italian & $\mathbf{- 3 . 4 5 4}$ & $<.01$ & 3.76 & .942 & 4.33 & .718 \\
\hline tourist agency employee - Spanish & $\mathbf{- 2 . 5 2 3}$ & $<.01$ & 3.64 & 1.06 & 4.10 & .848 \\
\hline tourist agency employee - French & $\mathbf{- 2 . 5 9 6}$ & $<.01$ & 3.55 & 1.157 & 4.08 & .953 \\
\hline
\end{tabular}

Legend: $M=$ Mean; $\sigma=$ Standard Deviation

As shown in Table 7, our study aimed to determine gender differences with regard to the level of difficulty of learning various foreign languages. Our participants were asked to rank the following foreign languages: English, French, German, Spanish and Italian according to the given scale: 1- most difficult to learn, 2- difficult, 3- neither difficult nor easy, 4- easy, 5- easiest. Our research has revealed that there is only one statistically significant difference with regard to the difficulty of learning certain foreign languages according to participants' gender (in the category which language is hard to learn). Male students consider Italian to be more difficult to learn (comparing with female students), while female students perceive Spanish to be harder to learn (as compared to the male students). 
Table 7 Chi square-tests about the difficulty of learning certain foreign languages according to participants' gender

\begin{tabular}{|c|c|c|c|c|c|c|c|}
\hline & English & German & Italian & French & Spanish & Russian & Chi square \\
\hline & \multicolumn{7}{|c|}{ Hard to learn } \\
\hline Male & 2 & 9 & 26 & 17 & 4 & & \multirow[t]{2}{*}{$12.174^{*}$} \\
\hline Female & 1 & 3 & 16 & 29 & & & \\
\hline & \multicolumn{7}{|c|}{ The hardest language to learn } \\
\hline Male & 2 & 27 & 2 & 26 & 1 & & \multirow[t]{2}{*}{3.034} \\
\hline Female & 2 & 17 & 1 & 29 & & & \\
\hline & \multicolumn{7}{|c|}{ Not easy but not so hard to learn } \\
\hline Male & 7 & 19 & 6 & 6 & 20 & & \multirow[t]{2}{*}{4.385} \\
\hline Female & 6 & 22 & 3 & 1 & 17 & & \\
\hline & \multicolumn{7}{|c|}{ Easy to learn } \\
\hline Male & 6 & 21 & & 7 & 24 & & \multirow[t]{2}{*}{5.187} \\
\hline Female & 3 & 18 & & 1 & 27 & & \\
\hline & \multicolumn{7}{|c|}{ The easiest language to learn } \\
\hline Male & 41 & 7 & & 1 & 9 & & \multirow[t]{2}{*}{1.588} \\
\hline Female & 38 & 6 & & & 5 & & \\
\hline
\end{tabular}

* Chi-square significant at $p<.05 ;{ }^{* *}$ Chi-square significant at $p<.01$

The main limitation of this research is relatively small and specific (non-representative of general population) sample of participants (RIT Croatia students in Dubrovnik). On the other hand, the same sample of participants may be also considered as an advantage since the population educated in this specific field can better reflect some really important aspects in tourism management. This survey has confirmed that foreign language proficiency is very important, but has to be differentiated by gender in specific fields of tourism planning, especially in the field of education of certain profiles of public or hospitality workers. Our main finding that female students are possibly more demanding tourists can be considered as a trend (it could indicate that women could be considered as more demanding tourists in general). The authors of this article believe that this is more than just a trend and that more recent findings in the field of second language acquisition also show that women use more language learning strategies than man $/ \mathbf{1 8} /, / \mathbf{1 9} /, / \mathbf{2 0} /, / \mathbf{2 1} /$, $/ 22 /, / 23 /$. It has been accepted as well that women usually have better communicational skills and since those skills are an absolute must in tourism. The authors of this paper feel that there is still space for further research in this area. Therefore, in order to improve overall hospitality industry offer in Dubrovnik the authors of this article strongly recommend learning of other foreign languages beside English. The authors suggest that it would be beneficial to investigate some other aspects such as the importance of knowledge of a particular foreign language in other professions related to tourism. The effects of such interventions are just some of the aspects that could be covered in future research.

\section{Conclusion}

Based on the results of the survey, our initial hypothesis has been partially rejected. We have found three statistically significant gender differences with regard to the role of the most important foreign language in the tourism and hospitality area in Dubrovnik. The results show that female students estimate Italian, German and French as most important foreign languages in the improvement of the overall offer in hospitality services, if compared to the male students. A few statistically significant gender differences in the importance of the knowledge of certain foreign languages in different services indicate the direction of higher means for female students. Only one statistically significant gender difference is found with regard to the difficulty of learning certain foreign languages. The results show that male students consider Italian to be more difficult to learn if compared to the female students. On the other hand, female students perceive Spanish as more difficult language to learn if compared to the male students. No statistically significant gender differences have been found with regard to the importance of the knowledge of different foreign languages between the elite and mass tourism as well as in various institutions and organizations which are responsible for the development of the city of Dubrovnik as a tourist destination. Therefore, our initial hypothesis can be partially confirmed. A key finding in our research is the fact that female students consistently consider 
knowledge of foreign languages as more important than male students. Since in most variables we have not found statistically significant differences, this conclusion cannot be accepted as an absolute rule.

This survey has indicated the need for continuous promotion of learning various foreign languages. The necessity to establish efficient communication which would allow interlocutors the exchange of the opinions and would raise awareness about the importance of foreign language proficiency for the development of responsible tourism is also discussed in this paper. One of the most important skills for tomorrow's Europe will definitively be the ability to communicate in more than one language. Encouraging people to learn other languages and understand other cultures will help to improve their communication and mutual understanding. It has also already been widely recognized that being able to communicate directly in a foreign language also brings cultural and economic benefits to all participants in the communication process. Therefore, raising awareness of the importance of foreign language proficiency and as well as fostering the development of intercultural competence in the area of tourism and hospitality industry is extremely important.

\section{Notes}

/1/ Fernandez S. (2008). Teaching and Learning Languages Other than English (LOTE) in Victorian Schools, [Retrieved April 27, 2011 from: http://www.eduweb.vic.gov.au/edulibrary/public/p $\mathrm{ubl} /$ research/publ/language-learning-report.pdf]

/2/ Vuković I. (2006). Suvremeni trendovi u razvoju turizma u Europskoj uniji i implikacije na Hrvatsku ("Modern trends in development of tourism within European Union and their implication upon Croatia"), Tourism and Hospitality Management, 12 (1), 3555.

/3/ Lasagabaster D. (2008). Foreign Language Competence in Content and Language Integrated Courses, The Open Applied Linguistics Journal, 1, 31-42.

/4/ Ellis R. (1986). Understanding Second Language Acquisition. Oxford: Oxford University Press.

/5/ Dörnyei Z. (2005). The Psychology of the Language Learner. Individual differences in Second Language Acquisition. London: Lawrence Erlbaum Associates, Inc.

16/ Common European Framework of Reference for Languages: Learning, Teaching, Assessment. (2001). Council of Europe. Cambridge University Press.
/7/ Canale M., Swain M. (1980).Theoretical bases of communicative approaches to second language teaching and testing. Applied Linguistics, 1, 1-47.

/8/ Bachman L.F., Palmer A.S. (1982). The construct validation of some components of communicative proficiency. TESOL Quarterly, 16, 449-465.

19/ Tarone E., Yule G. (1989). Focus on the Language Learner. Oxford: Oxford University Press.

/10/ Dörnyei Z., Csizér K. (2005). The Effects of Intercultural Contact and Tourism on Language Attitudes and Language Learning Motivation, Journal of Language and Social Psychology, 24 (4), 327-357.

/11/ Jessner, U. (2008). Teaching third languages: Findings, trends and challenges, Language Teaching, 41 (1), 15-56.

/12/ Ellis R. (2005). Instructed Second Language Acquisition. Wellington: Ministry of Education, New Zealand.

/13/ Williams M., Burden R.L. (1999). Psychology for language teachers. Cambridge: Cambridge University Press.

14/ Byram M. (2000). Assessing Intercultural Competence in Language Teaching. Sprogforum, 18 (6), 813.

/15/ Božinović N., Friganović-Sain Z., Perić B. (2011). Students' perceptions on the importance of foreign languages for careers in tourism. In J. Matic and C.J. Wallington (ed.) Tourism and Hospitality, Drivers of Transition, pp. 117-130. Proceedings of the 29th Annual EuroCHRIE Conference, Dubrovnik: American College of Management \&Technology.

/16/ Luka I. (2007). Development of Student's English for Special Purposes Competence in Tourism Studies at Tertiary Level. The paper presented at the International bilingual conference "Assessing language and (inter-) cultural competences in Higher Education" in Finland, the University of Turku, 3031. [Retrieved April 27, 2011 from http://www.turiba.lv/uploaded_files/Mig_Komm/ Language_competence.pdf]

/17/ Petrovska I. (2010). Teaching and Learning Pragmatics: Speech Strategies for HR Employers, Faculty of Tourism and Hospitality Management in Opatija. Bienniall International Congress. Tourism and Hospitality Industry, 1142-49.

/18/ Božinović N., Sindik J. (2011). Gender differences in the use of learning strategies in adult foreign language learners, Metodički obzori, 11, 17-31.

/19/ Gürata A. (2008). The grammar learning strategies employed by Turkish University Preparatory School EFL students. MA thesis, Bilkent University, Ankara.

/20/ Liu D. (2004). EFL Proficiency, Gender and Language Learning Strategy Use Among a Group of Chinese Technological Institute English Majors, ARECLS E-Journal, 1, A5. 
/21/ Oxford R. L., Nyikos M. (1989). Variables affecting choice of language learning strategies by university students. Modern Language Journal, 73, 2, 291300.

/22/ Oxford R. L., Nyikos M., Ehrman M. E. (1988). Vive la difference? Reflections on sex differences in use of language learning strategies. Foreign Language Annals, 21(4), 321-328.

/23/ Tilfarioğlu F.Y., Yalçin E. (2005). An Analysis of the Relationship Between the Use of Grammar Learning

\title{
PERCEPCIJE STUDENATA O VAŽNOSTI ZNANJA STRANIH JEZIKA U PODRUČJU TURIZMA U ODNOSU NA SPOL
}

\author{
Nikolina Božinović1 , Joško Sindik ${ }^{2}$ \\ Rochester Institute of Technology, RIT Hrvatska, Dubrovnik, Hrvatska1' Institut za antropologiju, Zagreb, Hrvatska²
}

\section{Sažetak}

Kompetencija u više stranih jezika predstavlja ključnu pretpostavku za uspješnu komunikaciju u turizmu. Turizam i mobilnost imaju značajnu ulogu, a interkulturalni kontakti doprinose izgradnji interkulturalnoga dijaloga. Cilj je ovoga članka utvrditi spolne razlike u percepciji studenata koji pohađaju Rochester Institute of Technology, RIT Croatia u Dubrovniku u odnosu na važnost znanja različitih stranih jezika u oblasti turizma. Dobiveni rezultati doprinijeti će podizanju svjesnosti o važnosti uloge učenja i poučavanja stranih jezika s potencijalnim učinkom razvoja i promocije turizma u Hrvatskoj. Najznačajniji rezultat dobiven u ovome istraživanju ukazuje da ispitanice generalno smatraju kompetenciju u stranome jeziku važnijom u odnosu na muške ispitanike. Ovaj nalaz također ukazuje da su žene potencijalno zahtjevniji turisti. U većini varijabli ovo istraživanje nije ukazalo na postojanje statistički značajnih razlika.

\section{Ključne riječi}

komunikacijska kompetencija, interkulturalna komunikacija u turizmu, odgovorni turizam, spolne razlike 